\title{
Lasten potilaskokemukset digitaalisten palveluiden kehittämisen lähtökohtana
}

\author{
Nina Karisalmi ${ }^{1}$, DI, lasten sair.hoit., Johanna Kaipio ${ }^{1}$, TkT, Pekka Lahdenne ${ }^{2}$, lastentaut. dosentti \\ ${ }^{1}$ Tietotekniikan laitos, Aalto-yliopisto, Espoo; ${ }^{2}$ Lastenklinikka, Helsingin yliopistollinen keskussairaala, Helsinki
}

Nina Karisalmi, DI, Tietotekniikan laitos, Aalto-yliopisto, Espoo, FINLAND. Sähköposti: nina.karisalmi@gmail.com

\section{Tiivistelmä}

Terveyspalveluja tarjoavat organisaatiot ovat entistä useammin kiinnostuneita asiakkaidensa - potilaiden - kokemuksista. Tässä artikkelissa raportoitava tutkimus on osa laajempaa tutkimushanketta, jossa selvitetään lapsipotilaiden ja heidän perheidensä näkemyksiä sairaalakäynneistä, saadusta hoidosta ja jokapäiväisestä elämästä sairauden kanssa.

Tutkimuksen tavoitteena oli selvittää, mitä asioita erikoissairaanhoidon piirissä olevat lapset pitävät omassa potilaskokemuksessaan tärkeinä ja arvokkaina. Näihin liittyen kuvataan, miten digitaaliset palvelut voisivat tulevaisuudessa nivoutua osaksi lasten potilaspolkuja ja tukea parempaa potilaskokemusta. Tutkimuksen aineisto kerättiin 10-16-vuotiailta pitkäaikaissairailta lapsilta videopäiväkirjan avulla. Tutkimukseen osallistui 14 lasta ja nuorta.

Tutkimuksen tuloksena saatiin selville, mikä lasten ja nuorten mielestä tällä hetkellä toimii heidän sairautensa hoidossa, missä asioissa on vielä parannettavaa sekä minkälaisia toiveita nuorilla on jatkossa hoitonsa suhteen. Nämä havainnot voidaan luokitella kolmeen teemaryhmään: fyysiset puitteet, lapsen ja perheen kohtaaminen, hoidon helppous ja järkevyys. Lapset ja nuoret arvostavat esimerkiksi toimivia ja viihtyisiä tiloja, yksilöllistä ja lämmintä kohtaamista, hoidon jatkuvuutta sekä kontrollikäynnin ja sairauden hoidon helppoutta. Esiin nousseisiin parannettaviin asioihin voidaan vaikuttaa fyysisillä muutoksilla, sujuvoittamalla vuorovaikutustilanteita sekä digitaalisten palvelujen avulla. Tulevaisuudessa digitaalisten palveluiden voidaan nähdä olevan yksi keskeinen keino tukea parempaa lasten ja nuorten potilaskokemusta.

Avainsanat: potilaskokemus, lapset ja nuoret, videopäiväkirja, arvokkaat asiat, lastensairaala, potilaspolku, digitaaliset palvelut 


\section{Abstract}

Healthcare providers are increasingly paying attention to their customer's experiences - meaning experiences of patients. This article reports a study which is part of a larger Lapsus research project. The aim of the project is to explore the perceptions and the experiences of child patients and their families about their visits to the hospital, about the given treatment and care, and about their everyday life with the illness.

This article reports issues which children using special healthcare services consider as important and valuable in their experiences as patients. Basing on these issues the paper describes how digital services in the future can be incorporated in the patient paths of the children to enhance their patient experience. The study data was gathered from 10-16-year old chronically ill children with video diaries. All together 14 children participated in the study.

The results show which issues are working fine and which still need improvements in the treatment of the children, as well as future wishes the children have regarding their care. These observations can be categorized into three themes: physical aspects, communication with the child and the family as well as ease and rationality of the care. Other things the children found valuable were practical and cosy spaces, individual and warm communication with professionals, continuity of care, and ease of visits and care. With these findings in mind, the improvement activities should focus on physical alterations, points of interaction in various phases of patient paths and digital services. In the future digital services may become a pivotal way to support better patient experience of children and their families.

Keywords: patient experience, children and teenagers, video diaries, valuable issues, children's hospital, patient path, digital services

\section{Johdanto}

Terveydenhuollon palvelujen sisältöihin ja toteutukseen liittyy nykyisin aiempaa suurempia odotuksia [1,2]. Palveluiden tuottajat ovatkin alkaneet kiinnittää huomiota potilaskokemukseen ja nostaneet sen tärkeysjärjestyksessä korkealle [2]. Potilaskokemusten vertailua käytetään lisääntyvästi myös toiminnan arvioimisessa [3]. Institute of Medicine (IOM) pitää potilaskokemusta potilaskeskeisyyden mittana ja yhtenä terveydenhuolIon laadun tavoitteista [4]. Potilaskokemuksen arvioidaankin tulevaisuudessa muodostuvan yhdeksi tekijäksi, jolla voidaan erottaa hyvin ja heikommin toimivat terveydenhuollon palvelut toisistaan [5].

Jotta potilaskokemusta voitaisiin parantaa, on ensin ymmärrettävä, mitä potilaskokemus on ja mitä ollaan muuttamassa [6]. Tarvitaan myös potilaskokemuksen tarkempi määrittely ja tieto, miten potilaskokemusta voidaan tutkia tai mitata, jotta potilaskeskeisyyden tukeminen terveydenhuollossa mahdollistuu [1].
Vaikka sairaalat ja terveydenhuoltoyksiköt pyrkivät suunnittelemaan palvelujaan potilaskeskeisesti, jää niiltä valitettavan usein paras resurssi eli käyttäjäkeskeinen suunnittelu yhteistyössä potilaiden kanssa hyödyntämättä [5]. Sen sijaan usein käytetään standardimenetelmiä kuten kyselyitä ja fokusryhmiä [5]. Lasten kohdalla käännytään tyypillisesti heidän vanhempiensa puoleen, vaikka on selvää, etteivät vanhemmat yksinään edusta lasten näkemyksiä, koska heidän ja lasten tavoitteet esimerkiksi hoidoista voivat erota toisistaan [7].

Tässä artikkelissa esiteltävän tutkimuksen tavoitteena oli selvittää lasten omia potilaskokemuksia suoraan heiltä kysyttynä ja heidän itsensä kertomana. Artikkelissa raportoidaan, mitä asioita erikoissairaanhoidon piirissä olevat lapset pitävät omassa potilaskokemuksessaan tärkeinä ja arvokkaina sekä, miten digitaaliset palvelut voisivat tulevaisuudessa nivoutua osaksi lasten potilaspolkuja ja tukea parempaa potilaskokemusta. Tutkimus on osana laajempaa 'Lapsiperheen uudistuva 
sairaala - potilaskokemus palvelupolkujen arvon kehittäjänä' (Lapsus) -tutkimushanketta, joka on Aaltoyliopiston johtama ja TEKESin rahoittama. Hankkeen tavoitteena on tutkia lapsipotilaskokemusta käsitteellisellä tasolla sekä kehittää lastensairaalaympäristöön eri-ikäisille lapsille potilaspolun eri vaiheisiin soveltuvia potilaskokemuskyselyjä ja toimintamalleja kyselytulosten hyödyntämiseen.

\section{Taustaa}

\section{Yleistä potilaskokemuksesta}

Oxfordin tietosanakirja määrittää [8] kokemuksen olevan "tapahtuma, joka aikaansaa vaikutelman ja tunteen tai tuntemuksen". Määritelmässä korostuu jonkun tapahtuman vaikutus ihmiseen, jolloin toiminnan kautta syntyy ajatuksia ja tuntemuksia, joista muodostuu kokemus. Erilaisiin käyttötilanteisiin on luotu erilaisia määritelmiä, sillä käyttäjäkokemus voi näkyä eri yhteyksissä eri tavoin. Viime vuosina esiin on noussut potilaskokemus, joka on käyttäjäkokemuksesta johdettu termi
[9]. Molemmat kokemukset syntyvät vuorovaikutustilanteissa: Käyttäjäkokemuksessa kohteena ovat tuotteet ja palvelut, kun taas potilaskokemuksessa kohteena on terveydenhuoltopalveluiden käyttö ja siten myös sairaalaorganisaatio ja sen kulttuuri.

Terveydellä on suuri merkitys monelle, minkä johdosta on ymmärrettävää, että paitsi sairastaminen myös toipuminen vaikuttavat kokemukseen. Beryl Instituutin (2010) määritelmän mukaan potilaskokemus on summa kaikista organisaation kulttuurin aiheuttamista vuorovaikutuksista, jotka vaikuttavat potilaan havaintoihin koko hoidon keston aikana. Tutkija Greenfield ja muut tunnistivat potilaiden haastatteluista kuusi potilaskeskeisyyden keskeistä teemaa (kuva 1). Heidän mielestä potilaskokemus on parhaimmillaan, kun kaikkien näiden teemojen tarpeisiin vastataan. Yhteisesti hyväksyttyä määritelmää potilaskokemuksesta ei kuitenkaan kirjallisuudesta tällä hetkellä löydy. Tällainen määritelmä olisi hyödyllinen, sillä se tukisi potilaskeskeistä suunnittelua ja terveydenhuollon palvelujen arviointia loppukäyttäjän näkökulmasta [1].

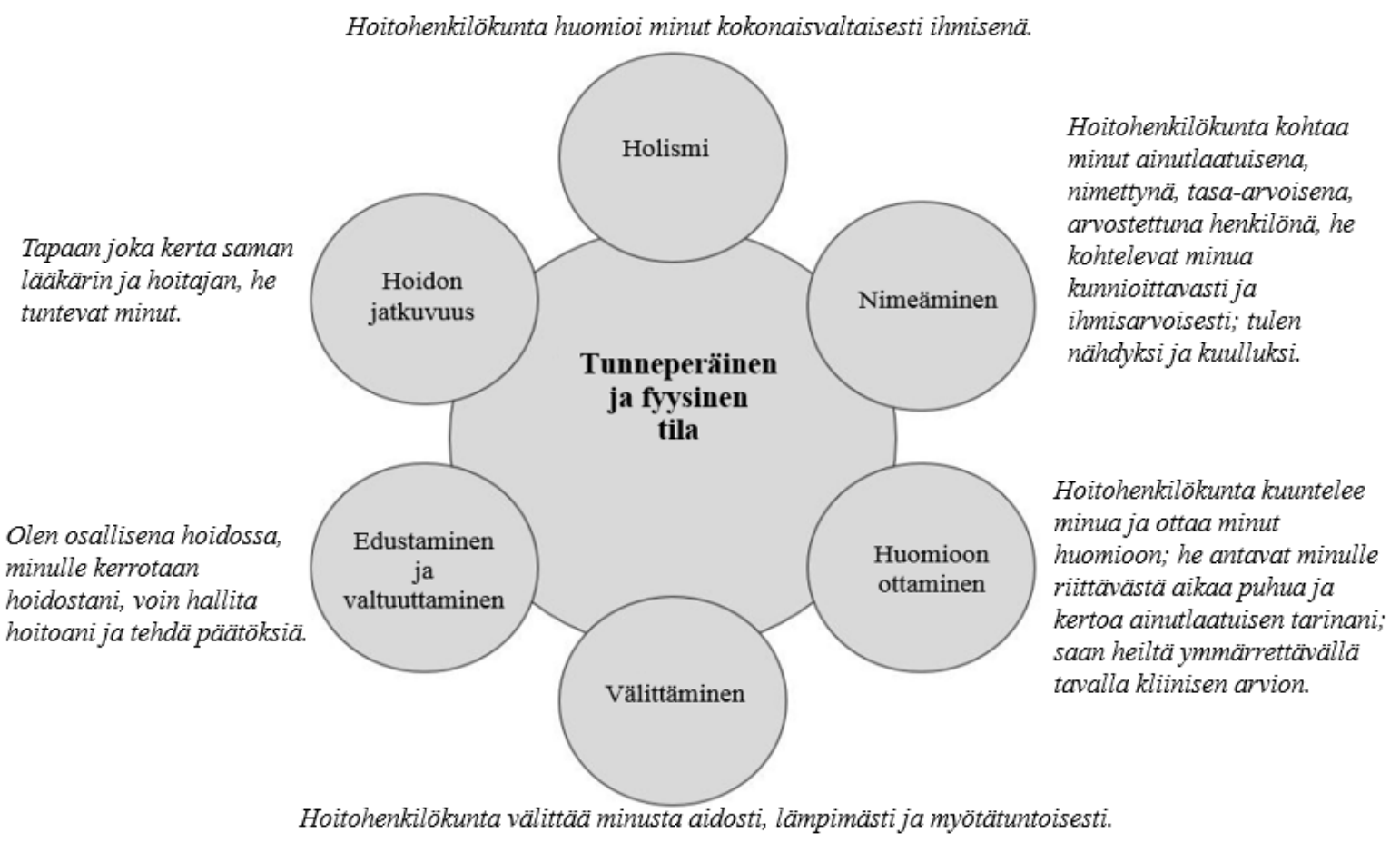

Kuva 1. Potilaskeskeisyyden keskeiset teemat, jotka vaikuttavat potilaskokemukseen, muokattu [10]. 
Terveydenhuollossa on havahduttu tarpeeseen ymmärtää nykyistä paremmin, miten potilaskokemus liittyy potilastyytyväisyyteen ja hoidon laatuun [11]. Potilaiden kokemukset ovat tärkeää tietoa terveyspalveluiden laatua arvioitaessa ja kehitettäessä, sillä potilaskokemus heijastaa hoidon laatua potilaan näkökulmasta [12]. Potilastyytyväisyys ei myöskään yksinään pysty selittämään potilaskokemusta [13], jolloin pelkän potilastyytyväisyyden parantaminen ei aina riitä. Hoidon laadun parantamiseksi potilaskokemusta on tärkeää mitata, koska se voi paljastaa puutteita ja ongelmia systeemitasolla [4]. Samalla on kuitenkin kyseenalaistettu, heijastavatko potilaiden kokemuskertomukset hoidon laadun todellisuutta, eikä yhteisymmärrystä potilaskokemuksen mittaamisen pätevyydestä hoidon laatua arvioidessa ole [14]: Osa tutkimuksista osoittaa potilaskokemuksen mittaamisen olevan yhteydessä parempiin lopputuloksiin ja osa tutkimuksista osoittaa päinvastaista. Hyvän potilaskokemuksen on todettu vaikuttavan positiivisesti hoitomyönteisyyteen ja osallistumishalukkuuteen [4].

Potilaskokemus on monitahoinen ja monimutkainen, minkä vuoksi sen mittaaminen on vaikeampaa kuin muiden hoidon laadun osa-alueiden [15]. Näin ollen potilastyytyväisyyden mittauksilla ei päästä käsiksi potilaskokemuksen monimuotoisuuteen ja kerroksellisuuteen, vaan tarvitaan potilaiden kertomuksia [16]. Haastattelut ja kyselyt keskittyvät usein alueisiin, joita terveydenhuoltohenkilöstö pitää tärkeänä. Sen sijaan potilaskeskeisillä kerrontamenetelmillä voidaan saada esille potilaiden kertomuksia, jotka perustuvat heidän omiin kokemuksiinsa ja mieltymyksiinsä [17]. Potilaiden kertomukset tarjoavat terveyspalveluja tuottaville organisaatioille mahdollisuuden saavuttaa parempi ymmärrys potilaiden palvelukokemuksista [18]. Tehokkaimpana tapana potilaskokemuksen tutkimiseksi ja kuvailemiseksi pidetään yhdistelmää kvantitatiivisesta potilastyytyväisyystutkimuksesta ja laadullisesta potilaskeskeisestä kerrontamenetelmästä [19].

\section{Lasten ja nuorten tarpeiden sekä kokemuksen tutkimi- nen}

Lasten ja nuorten potilaskokemuksesta löytyy akateemisesta kirjallisuudessa vähän tutkimusjulkaisuja. Ylipäätään lasten ja nuorten tarpeita on kartoitettu hyvin vähän. Yhtenä esimerkkinä tarpeiden selvittämisestä on Mannerheimin Lastensuojeluliiton (MLL) ylläpitämä valtakunnallinen ja maksuton auttava puhelin "Lasten ja nuorten puhelin", joka vastaanottaa vuosittain noin 35000 puhelua, nettikirjettä ja chat-keskustelua. MLL on tilastoinut keskustelupuheluiden soittajat ikäryhmittäin, puhelutyypeittäin sekä puheluteemojen mukaan. Vuoden 2015 auttavan puhelimen raportista [20] selviää, että $47 \%$ aiheista merkittiin yhteydenotoiksi lapsilta ja nuorilta, jotka kokivat arjessaan yksinoloa tai yksinäisyyttä. Näistä suurin osa eli $26 \%$ oli keskustelemista päivän kuulumisista. Seksuaalisuus, vertaissuhteet sekä koulu ja vapaa-aika olivat arjen yksinäisyyden jälkeen suurimmat puheluteemat.

Tutkimuskirjallisuudesta löytyy jonkin verran tietoa sairastavien lasten ja nuorten tarpeista ja kokemuksista. Vaikka tarpeisiin on alettu kiinnittää enenevissä määrin huomiota, löytyy silti vain muutamia tutkimuksia lasten potilaskokemuksesta. Coyne selvitti puolistrukturoitujen haastattelujen avulla 7-14-vuotiaiden lasten kokemuksia sairaalassaolosta [21]. Tutkimukseen osallistui 11 lasta neljästä lastensairaalan yksiköstä Englannissa. Tutkimuksessa tunnistettiin neljä eri pelon ja huolen aihetta nuorilla: vanhemmista ja perheestä erossa oleminen, tuntematon sairaalaympäristö, tutkimukset ja hoidot sekä itsemääräämisoikeuden häviäminen. Tulokset osoittivat, että iänmukainen lasten informointi on tärkeää ja että sairaalaympäristö on tehtävä lapsikeskeisemmäksi [21]. Näillä parannuksilla ei ainoastaan vähennettäisi lasten stressiä sairaalassa oloaikana, vaan todennäköisesti vaikutettaisiin myös tuleviin sairaalakokemuksiin.

Myös Ruotsissa [22] ja Skotlannissa [23] on selvitetty lasten ja nuorten kokemuksia sairaalan lastenosastoilla. Ruotsissa tutkimukseen osallistui seitsemän 7-10vuotiasta lasta, joilla oli lyhytaikainen sairaus. Heitä haastateltiin puolen vuoden sisään kotiutumisesta. Tutkimuksessa selvisi, että lasten kertomuksissa todelli- 
suus ja mielikuvitus sekoittuivat ja toisaalta eroavaisuuksia esiintyi niin lasten välillä kuin saman osallistujan vastauksissa. Skotlannissa tutkimukseen osallistui 213 iältään 4-17-vuotiasta lasta kahdelta lastenosastolta. Kotiuttamisjärjestyksen mukaan lapsi vastasi yhteen neljästä eri kyselyvaihtoehdosta: strukturoitu tai puolistrukturoitu verbaalinen kysely tai strukturoitu tai puolistrukturoitu visuaalinen kysely. Vastausten tunnistetut teemat olivat yleisesti positiivisia ja liittyivät pääasiassa lasten fyysiseen ympäristöön.

Lontoon ympäristössä on selvitetty, mitä 4-19-vuotiaat avohoito- ja sairaalapotilaat kokevat positiivisena ja negatiivisena paikallisissa terveyspalveluissa [24]. Tutkimus toteutettiin riippuen osallistujan tarpeista ja taidoista joko haastattelulla, leikkimenetelmällä tai internetsivun kautta. Tutkimukseen osallistui yhteensä 149 lasta ja nuorta. Vastauksissaan varsinkin nuoret painottivat kommunikointia ja suhdetta hoitohenkilökunnan kanssa. Myös terveyspalveluiden ympäristöön liittyvät asiat nousivat esille. Englannissa on lisäksi selvitetty lapsiperheiden kokemuksia sairaala- ja kotihoidosta [25]. Vanhempien lisäksi yhtätoista 5-12-vuotiasta lasta haastateltiin ja heitä pyydettiin piirtämään. Suurin osa sekä vanhemmista että lapsista suosivat kotihoitoa.

Edellisistä poiketen Suomessa on tutkittu lasten kokemaa kipua ja liittyviä tapahtumia [26]. Haastateltaviksi valikoituivat 44 iältään 4-11-vuotiasta lasta yliopistollisen sairaalan eri osastoilta. Tutkimuksesta selvisi, että lasten kipukokemukset voidaan jakaa neljään ryhmään: 1) kipu oireena diagnosoidusta sairaudesta, 2) tutkimusja hoitotoimenpiteiden aiheuttama kipu, 3) tapaturman aiheuttama kipu ja 4) selittämätön kipu, joka ei aiheudu mistään tietystä sairaudesta tai vammasta.

\section{Uuden lastensairaalan toiminnan kehittäminen, digi- taaliset palvelut ja potilaskokemuksen mittaaminen}

Helsingin yliopistollisen keskussairaalan (HYKS) Meilahden kampuksella käynnistyi vuonna 2012 uuden lastensairaalan rakentamishanke, jonka ensisijaisena ajurina oli käytössä olevien rakennusten - Lastenklinikka ja Lastenlinna - huonokuntoisuus ja ahtaus sekä talotekniikan, lääketieteellisen teknologian että perhekeskei- sen hoidon näkökulmista. Molemmat rakennukset ovat valmistuneet 1940-luvun lopussa, ja ne eivät enää sovellu nykyaikaisen sairaalatoiminnan vaatimuksiin.

Uusi lastensairaalahanke on alusta lähtien ollut suurelta osin myös toiminnan kehittämishanke. Tavoitteena uusien toimintojen ja tilojen suunnittelussa on ollut lääketieteellisen hoidon ja tutkimuksen korkean laadun ylläpitäminen tai parantaminen, toiminnan kustannustehokkuuden lisääminen ja erityisesti hyvän potilaskokemuksen tuottaminen lapsipotilaille ja heidän perheilleen.

Uuden lastensairaalan suunnittelun alkuvaiheessa toteutettiin HYKS Lastensairaalassa hoidossa olleiden lasten perheille laaja kyselytutkimus, jolla kartoitettiin perheiden kokemuksia ja odotuksia uuden lastensairaalan toiminnoista ja tiloista. Jatkosuunnittelun aikana toimintaprosessien kehittämisessä havainnollistui vanhemmilta saatujen tietojen lisäksi tarve kuulla ja selvittää potilaskokemuksia suoraan lapsilta ja nuorilta. Menetelmiä lapsilta suoraan saatavan kokemustiedon keräämiseksi ei aiemmin ole ollut käytettävissä.

Digitaalisten palveluiden osuus julkisen terveydenhuolIon palveluissa, kuten esimerkiksi HYKS Lasten ja nuorten sairauksien toimialalla, on ollut pieni tai olematon. Keskeisenä kehityskohteena uudessa lastensairaalassa onkin uudenlaisten digitaalisten palveluiden integroiminen osaksi sairaalassa tarjolla olevia perinteisiä palveluita. Erityisesti nuorten kohdalla hypoteesina on, että digitaalisten palveluiden avulla nuorten potilaiden aktivoituminen itsehoitoon ja kiinnittyminen sairaalahoitoon voisi merkittävästi parantua.

\section{Tutkimuksen esittely}

\section{Tutkimuksen tavoite ja kohdejoukko}

Tutkimuksen tavoitteena oli selvittää lasten omia potilaskokemuksia suoraan heiltä kysyttynä ja heidän itsensä kertomana. Tutkimuksen kohdejoukon muodostivat terveydenhuoltopalveluja käyttävät 10-16-vuotiaat lapset, joilla oli pitkäaikaissairaus. Tutkimus toteutettiin tammi-toukokuussa 2016 ja osallistujat rekrytoitiin HYKS:n Lastensairaalan reuma-, diabetes- ja suolistopo- 
liklinikoilta. Tutkimuksen avulla etsittiin vastauksia seuraaviin kysymyksiin:

- Mikä tällä hetkellä toimii lasten mielestä heidän sairautensa hoidossa?

- Mikä ei toimi lasten mielestä?

- Millaisia toiveita lapsilla on sairastamiseensa ja hoitoonsa liittyen?

\section{Menetelmä ja tutkimuksen toteutus}

Tutkimus toteutettiin videopäiväkirjamenetelmän avulla [27]. Videopäiväkirja valikoitui menetelmäksi, koska sen avulla saadaan syvällisempää tietoa [28], varsinkin lasten kohdalla [29], ja voidaan saada selville asioita, joita ei muilla menetelmillä saataisi [29, 30, 31]. Koska avoimilla kysymyksillä on todettu saatavan syvällisempää tietoa kuin suljetuilla kysymyksillä [32], osallistujat vastasivat videotallenteissaan avoimiin kysymyksiin, jolloin he saivat vastata omin sanoin ja painottaa itselle merkityksellisiä asioita.

HYKS Lastensairaalan kanssa yhteistyössä laadittiin tutkimuksenesittely ja suostumus noudattaen HYKS:n käytäntöjä tämän tyyppisen aineiston keruussa. Tämän jälkeen oltiin yhteydessä Lastensairaalan poliklinikoiden

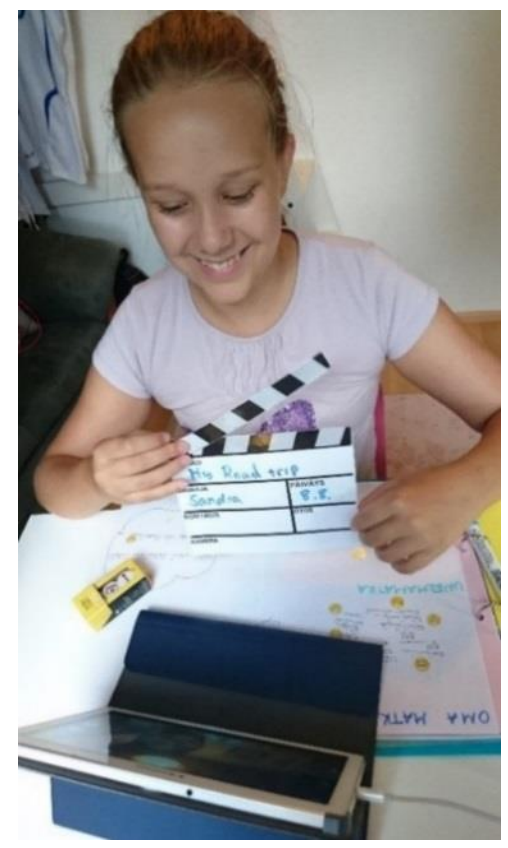

Kuva 2. Osallistuja kuvaamassa videopäiväkirjaa [27]. lapsipotilaiden vanhempiin. Mikäli perhe ja lapsi olivat halukkaita osallistumaan tutkimukseen, toimitettiin lapselle luotainpaketti, joka sisälsi lainakäyttöön videopäiväkirjan kuvaamisen tarkoitetun tablettitietokoneen (kuva 2), sekä kansion, jossa oli tulostettuna kuvalliset ohjeet, Lapsus-projektin tutkimustiedote, suostumuslomakkeet, lyhyt tablettitietokoneen käyttöohje, tehtävät, kolme tarinanoppaa, klaffi ja vesiliukoinen tussi.

Tutkimukseen osallistuvat lapset pitivät 9-10 päivän ajan videopäiväkirjaa, ja heidän arvioitiin käyttävän päivittäin tehtäviin 10-20 minuuttia. Kansion tehtävät liittyivät seuraaviin aiheisiin: sairauden ja kontrollikäyntien rakenne sekä niiden näkyminen ajan ja paikan suhteen, sairauden aiheuttamat tunteet ja aistimukset sekä sairastamisen sosiaalinen ulottuvuus. Kansiossa oli päivittäinen lyhyt vakiotehtävä, jonka lisäksi oli yhdeksän vaihtuvaa tehtävää (kuva 3). Näistä yhden sai halutessaan tehdä joko päivän tai kahden aikana. Lapsen oli tarkoitus tehdä ensin kansion tehtävä, minkä jälkeen hänen pyydettiin kertovan kameralle tehtävän mukaiset asiat. Koko tutkimuspaketin sisältö näkyy kuvassa 4. Tutkimuspaketin palauduttua 1-2 viikkoa myöhemmin toteutettiin lapsen kanssa loppuhaastattelu, jolloin tutkijalla oli mahdollisuus esittää tarkentavia kysymyksiä. 


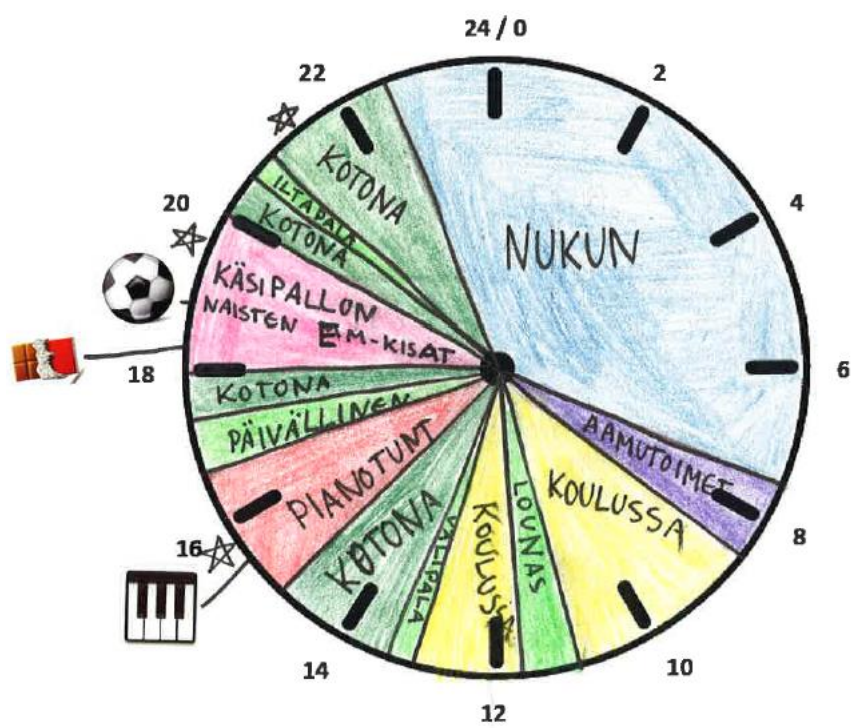

$\$=$ Tarked tapahtuma

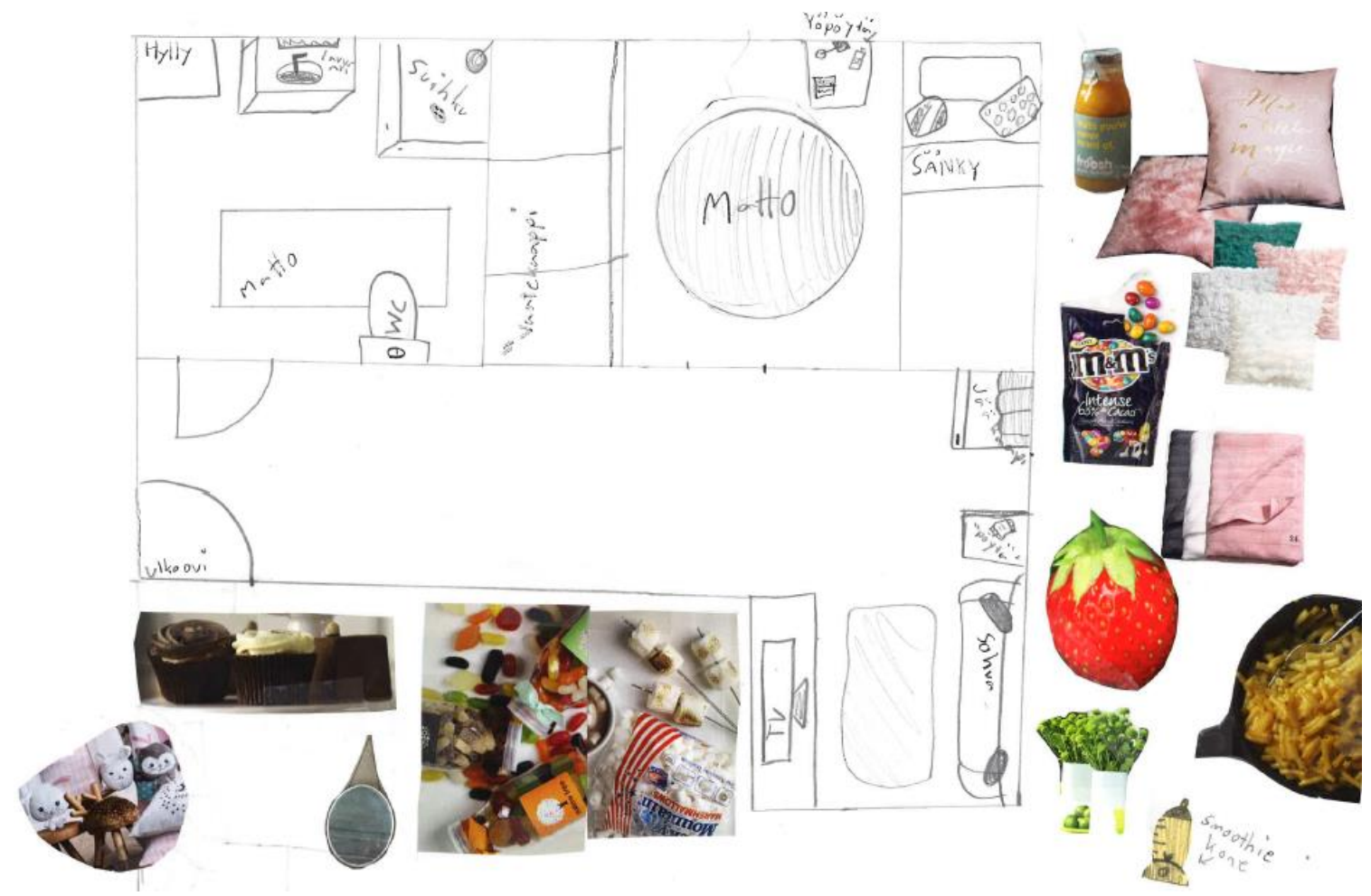

Kuva 3. Yllä päivittäinen vakiotehtävä. Alla päivittäinen vaihtuva tehtävä: tässä "Sairaalaloma" [27] 


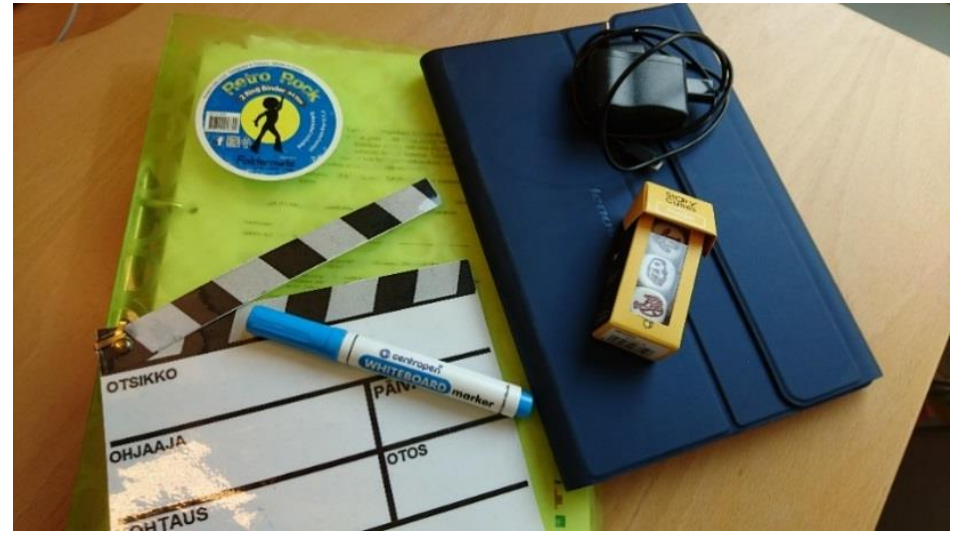

Kuva 4. Luotainpaketin sisältö [27].

\section{Eettiset kysymykset}

Aiheena sairastaminen - varsinkin lasten kohdalla - on arka ja eettisyys on otettava huomioon tutkimuksen aineistoa kerätessä ja sitä analysoitaessa. Tutkimukselle anottiin tutkimuslupa Helsingin ja Uudenmaan sairaanhoitopiirin (HUS) Lasten ja nuorten sairauksien, naistentautien ja synnytysten ja psykiatrian eettiseltä toimikunnalta. Toimikunta myönsi luvan elokuussa 2015 ja lupa koskee koko Lapsus-tutkimushanketta.

Toimikunnan pyynnöstä eri-ikäisille lapsille tehtiin omat suostumuslomakkeet (6-10-vuotiaille, 11-14-vuotiaille ja 15-17-vuotiaille). Lisäksi Suomessa vaaditaan alle 18vuotiailta osallistujilta lapsen oman suostumuksen lisäksi tämän vanhemman lupa osallistua. Suostumuslomakkeet lähetettiin yhdessä tutkimustiedotteen kanssa tutkimukseen osallistuvan perheen vanhemmalle ensimmäisen puhelinsoiton yhteydessä, jonka jälkeen lapsi ja vanhemmat saivat tutustua niihin etukäteen. Tutkimustiedotteessa kuten myös luotainpaketin ohjeissa korostettiin, että lapsella on mahdollisuus jättää tutkimus halutessaan kesken eikä tämä vaikuta hänen saamaansa hoitoon. Osallistujista kahdeksan käytti tätä mahdollisuutta, tosin heistä kaksi olivat halukkaita suorittamaan tutkimuksen syvähaastattelun muodossa.

\section{Aineisto ja analyysi}

Kun luotainpaketti palautui tutkijalle, tehtäväkansio skannattiin ja läpikäynnin yhteydessä tehtiin muistiinpanoja kansiosta esille nousevista asioista ja avoimiksi jääneistä kysymyksistä. Tämän jälkeen videopäiväkirjatallenteet katsottiin läpi, kirjoitettiin puhtaaksi ja tehtiin vastaavalla tavalla muistiinpanoja. Näin toimimalla haluttiin varmistaa, ettei videoiden katsominen aiheuttanut ennakkokäsityksiä. Kansiosta ja videoista saadut tiedot käytiin läpi ja nostettiin esille kysymyksiä ja aihealueita, joihin haluttiin loppuhaastattelun aikana saada selvennystä tai lisätietoa. Loppuhaastattelusta kirjoitettiin pääkohdat ja omat huomiot ylös. Laadullinen aineisto analysoitiin rakentamalla analyysirunko. Aineisto käytiin läpi käyttäen apuna Atlas.ti-ohjelmaa ja merkattiin analyysirungon pohjalta koodit. Aineisto analysoitiin anonyymisti ja ainoat yksilöivät tiedot olivat ikä, sukupuoli ja sairaus.

Tutkimusaineisto koostuu 14 vastaajasta, jotka osallistuivat videopäiväkirjan pitoon. Videoiden kesto oli 3 sekuntia-7,5 minuuttia, keskimäärin ne kestivät 2-5 minuuttia. Loppuhaastatteluiden kesto oli 36-85 minuuttia, keskimäärin 55 minuuttia.

\section{Tulokset}

\section{Taustatiedot osallistujista}

Tutkimukseen osallistui 14 lasta, joista $79 \%$ oli tyttöjä ja 64 \% oli iältään 14-16 -vuotiaita. Osallistuneilla oli seuraavia pitkäaikaissairauksia: reuma (6), diabetes (5) ja suolistosairaus (3). Taulukossa 1 on esitetty tarkemmat taustatiedot tutkimukseen osallistuneista. 
Taulukko 1. Tutkimukseen osallistuneitten lasten ja nuorten taustatiedot [27].

\begin{tabular}{cll}
\hline \multirow{2}{*}{ Sukupuoli } & Poika & 3 \\
& Tyttö & 11 \\
\hline & $10 \mathrm{v}$ & 2 \\
& $11 \mathrm{v}$ & 1 \\
& $12 \mathrm{v}$ & 2 \\
& $13 \mathrm{v}$ & 0 \\
& $14 \mathrm{v}$ & 4 \\
& $15 \mathrm{v}$ & 3 \\
& $16 \mathrm{v}$ & 2 \\
\hline \multirow{2}{*}{ Diagnoosi } & Reuma & 6 \\
& Suolistosairaus & 3 \\
& Diabetes & 5 \\
\hline
\end{tabular}

\section{Sairaalassa toimivat ja paranneltavat asiat}

Tutkimuksen perusteella lapset ja nuoret kokivat, että useat asiat toimivat tällä hetkellä hyvin heidän hoidossaan. Toimiviksi koetut asiat sisälsivät sekä yksittäisiä asioita, kuten lehdet ja TV-ohjelmat varsinkin nuoremmille lapsille, että myös hoitokäytäntöihin liittyviä seikkoja, esimerkiksi lääkärin keskustelun ensin nuoren kanssa kahden kesken ennen vanhemman mukanaoloa. Näiden lisäksi tutkimus nosti esiin asioita, joissa olisi parantamisen varaa (Taulukko 2). Asiat on ryhmitelty seuraavien teemojen mukaan: kohtaaminen, yleiset hoidon järjestelyt, sairaalan tilat ja viihtyminen.

\section{Toiveet tulevaisuuden sairaalalle}

Tutkimuksessa selvitettiin myös lasten toiveita tulevaisuuden hoidon ja sairaalan suhteen. Toiveet järjestettiin teemoittain sen mukaan, koskivatko ne lasten tiedon tarvetta, sairaalan tiloja, kontrollikäyntejä, yleisesti hoidon järjestelyjä vai lapsen viihtymistä sairaalassa (Taulukko 3). Osa teemoista on samoja kuin edeltävässä taulukossa 2 (sairaalassa toimivat asiat, paranneltavat asiat sairaalassa). 
Taulukko 2. Osallistujien mielipiteet toimivista ja paranneltavista asioista

\begin{tabular}{|c|c|c|}
\hline Teema & Sairaalassa toimivat asiat & Paranneltavat asiat sairaalassa \\
\hline \multirow[t]{8}{*}{ Kohtaaminen } & Kohdataan yksilönä & $\begin{array}{l}\text { Ei kohdata yksilönä, vain sairaus huomioidaan, ei em- } \\
\text { patiaa }\end{array}$ \\
\hline & Jutellaan muustakin kuin sairaudesta & $\begin{array}{l}\text { Kerrotaan asiat liian jyrkästi, eli tulisi kiinnittää huo- } \\
\text { miota miten kerrotaan }\end{array}$ \\
\hline & Saa söpöjä laastareita & Ei kohdata iloisesti, puhutaan vain sairaudesta \\
\hline & & $\begin{array}{l}\text { Psykiatri ymmärtää paremmin kuin lääkäri, lääkäri } \\
\text { miettii vain, että sairaus hoidettava, ei ajattele miltä } \\
\text { lapsesta tuntuu }\end{array}$ \\
\hline & & Hoitaja ei kuuntele \\
\hline & & $\begin{array}{l}\text { Tilannetaju puuttuu: heti diagnoosin saamisen jälkeen } \\
\text { ei jaksa tehdä koulutehtäviä }\end{array}$ \\
\hline & & $\begin{array}{l}\text { Ristiriitaiset ohjeet: sanotaan jotain, mutta toimii eri } \\
\text { tavalla }\end{array}$ \\
\hline & & $\begin{array}{l}\text { Joutuu olemaan pelkillä pikkuhousuilla eri sukupuolen } \\
\text { omaavan lääkärin edessä }\end{array}$ \\
\hline \multirow[t]{5}{*}{$\begin{array}{l}\text { Yleiset hoidon } \\
\text { järjestelyt }\end{array}$} & Jatkuvuus eli omahoitaja/-lääkäri & $\begin{array}{l}\text { Liian aikaiset kontrollit, pitkän matkan päässä, ajettava } \\
\text { ruuhkassa }\end{array}$ \\
\hline & $\begin{array}{l}\text { Vanhemmat mukana käynnillä koko } \\
\text { ajan (varsinkin nuoremmat lapset) }\end{array}$ & Hoitaja käy aina samat asiat läpi, turhauttaa \\
\hline & $\begin{array}{l}\text { Ensin yksin lääkärille, sitten lääkäri } \\
\text { selostaa vanhemmalle (yleensä } \\
\text { nuoret) }\end{array}$ & $\begin{array}{l}\text { Turhaa mitata normi verensokeri aamulla, koska se } \\
\text { joka tapauksessa on korkea aamupalan jälkeen }\end{array}$ \\
\hline & $\begin{array}{l}\text { Lapsilla on Keravalla oma nappi } \\
\text { laboratoriossa eli pääsevät nope- } \\
\text { ammin }\end{array}$ & \\
\hline & $\begin{array}{l}\text { Kaikki toiminnot ovat samalla käytä- } \\
\text { vällä }\end{array}$ & \\
\hline \multirow[t]{3}{*}{ Sairaalan tilat } & Tilat tilavat, hyvä ilmastointi & Sairaalamaista, ahdistavia, valkoisia seiniä \\
\hline & Hyvät opasteet & Huonot, rumat penkit \\
\hline & & $\begin{array}{l}\text { Lääkärin vastaanotolla pöytä sijoitettu siten, että lääkä- } \\
\text { ri on kirjoittaessaan selin potilaaseen, lisäksi vanhem- } \\
\text { pien tuolit kaukana huoneen toisella puolella, joten } \\
\text { tuntuu kuin he olisivat sivustaseuraajia }\end{array}$ \\
\hline \multirow[t]{2}{*}{ Viihtyminen } & $\begin{array}{l}\text { Lehtiä yms. tekemistä on riittävästi } \\
\text { nuoremmille lapsille }\end{array}$ & $\begin{array}{l}\text { Lehtiä yms. tekemistä on vanhemmille lapsille liian } \\
\text { vähän }\end{array}$ \\
\hline & Kahviossa käynti on kivaa & \\
\hline
\end{tabular}


Taulukko 3. Lasten ja nuorten toiveet tulevaisuuden hoidoista ja sairaalasta.

\begin{tabular}{|c|c|}
\hline Teema & Toive \\
\hline $\begin{array}{l}\text { Tiedollinen } \\
\text { tarve }\end{array}$ & $\begin{array}{l}\text { Laite tai paikka, jolloin tieto saadaan nopeasti ja reaaliaikaisesti, sen jälkeen suositus tai oh- } \\
\text { jeistus mitä tehdä } \\
\text { Tieto miten sairautta voisi ennaltaehkäistä }\end{array}$ \\
\hline Kontrollikäynti & $\begin{array}{l}\text { Tapahtuu huoneessa, johon tulevat lääkäri, laboratorio, yms. eli ei itse tarvitse kiertää paikko- } \\
\text { ja kenties leikkaussalivaatteissa } \\
\text { Mahdollisuus lepoon } \\
\text { Lounas tarjotaan sairaalan puolesta } \\
\text { Lyhyempi kokonaiskesto, alkaa myöhemmin ja ei olisi pitkä matka kotoa: ei verinäytettä, ei } \\
\text { kortisonipiikkiä, ei röntgeniä, ei fysioterapiaa. Lyhyt kokonaiskesto mahdollistaa sen että } \\
\text { ulkokuntalaiset voisivat käydä keskustassa ostoksilla yms. }\end{array}$ \\
\hline $\begin{array}{l}\text { Yleiset hoidon } \\
\text { järjestelyt }\end{array}$ & $\begin{array}{l}\text { Lääkäri alkaisi ajallaan } \\
\text { Sairaanhoitaja kertoo käynnillä jotain uutta, esimerkiksi uudesta hoitokeinosta } \\
\text { Sairaudesta huolimatta olisi vapauden tunne! } \\
\text { Diabetesta olisi helpompi hoitaa: } \\
\text { - Puhelinsovellus } \\
\text { - Helppo, huomaamaton verensokerin mittaus } \\
\text { - Jatkuva verensokerin mittaus } \\
\text { - Laite pistää myös pitkävaikutteisen insuliinin } \\
\text { - } \quad \text { Loi tarkastella arvoja aina kun haluaa } \\
\text { - Laite hoitaisi haiman virkaa } \\
\text { Pidemmällä vuodeosastojaksolla nuoret voisivat opetella itse tekemään ruokaa, pestä pyykkiä } \\
\text { Non-invasiiviset laitteet } \\
\text { Oma huone, jossa mahdollisesti on vessa tukemaan omaa rauhaa ja yksityisyyttä ja käytännöl- } \\
\text { lisyyttä }\end{array}$ \\
\hline $\begin{array}{l}\text { Kodinomaiset ja } \\
\text { käytännölliset } \\
\text { sairaalan tilat }\end{array}$ & $\begin{array}{l}\text { Poliklinikoilla kahviautomaatti } \\
\text { Avaruus, isot ikkunat, joista kaunis maisema } \\
\text { Potilashuoneessa oleskelutila, lepotila, keittiö, parveke/terassi, grilli, aurinkotuolit } \\
\text { Potilashuoneessa kylpyamme, poreallas, yöpöytä, sohva, nojatuoli, säkkituoli, pöytä, laava- } \\
\text { lamppu } \\
\text { Värikkäitä pyyhkeitä, sisustustyynyjä } \\
\text { Vanhemmalle oma sänky/ nojatuolista sänky/ leveämpi sänky, jotta voi nukkua vanhemman } \\
\text { vieressä } \\
\text { Sängyt leveämpiä, mukavampia, pehmeämpiä }\end{array}$ \\
\hline
\end{tabular}


Enemmän järjestettyä toimintaa kuten sairaalapellet

Sairaalasta saisi oman pehmolelun mukaan

Sairaalassa tarjolla herkkuja: pitsaa, jäätelöä, hattaraa, karkkeja, muffinseja

Viihtyminen

Riittävästi mielekästä tekemistä eri-ikäisille: pelihuone, pallomeri, lautapeli, palapeli, keilat, askartelu, piirustus, TV, Play Station, musiikkia, videot, tietokone, biljardi, sairaalakoulu

Ilmainen Wifi

Potilashuoneessa smoothiekone, suklaaputous, popcornkone, jääkaappi ja mikro

\section{Pohdinta ja johtopäätökset}

Aineiston pohjalta voidaan sanoa, että lasten potilaskokemus kattaa niin hoidon jatkuvuuden ja hoitoon osallistumisen kuin heidän välittävän, kokonaisvaltaisen ja kunnioittavan huomioon ottamisen. Näin ollen Greenfieldin tutkijaryhmän nimeämät kuusi potilaskokemuksen teemaa [10] näkyvät tässäkin tutkimuksessa. Osa teemoista korostuu lasten kokemuksissa toisia enemmän. Näitä korostuvia teemoja ovat hoidon jatkuvuus, lasten kohtaaminen kokonaisvaltaisesti ja hoitotoimenpiteiden non-invasiivisuus. Yksi keskeinen löydös on, että pitkäaikaissairaat lapset eivät peilaa elämäänsä sairautensa vaan arjen tapahtumien kautta [27]. Saman perheen vanhemman haastattelua ja lapsen videopäiväkirjaa vertailemalla selvisi, että vanhemmat miettivät lapsensa tulevaisuutta enemmän ja pidemmälle kuin lapsi itse [27]. Lapset tuntuvat elävän enemmän tässä hetkessä ja harmittelevat konkreettisia asioita kuten ruokarajoituksia ja herkkujen välttämistä.

Tutkimuksessa kerättyä aineistoa voidaan kuvata runsaaksi ja sekä verbaalisesti että visuaalisesti rikkaaksi. Osallistuneiden lasten ja nuorten mukaan moni asia toimi hyvin heidän hoidossaan, eikä niitä ole syytä muuttaa pelkän muutoksen takia. Asioihin, joissa vastaajien mukaan oli parantamisen varaa, on tärkeää kiinnittää huomiota, koska yksittäinen negatiivisesti sävyttynyt kokemus voi pilata muutoin positiivisen kokonaiskokemuksen. Tulosten perusteella toimiviksi koetuissa asioissa on eroja eri vastaajien välillä liittyen vastaajien henkilökohtaisiin kokemuksiin. Toiset vastaajista esimerkiksi kokivat, että heidät huomioidaan yksilöinä ja keskustellaan muustakin kuin pelkästä sairau- desta ja sen hoidosta, kun taas osan mielestä näissä asioissa oli parantamisen varaa.

\section{Lasten kokemat arvokkaat asiat}

Tutkimuksen tuloksena tunnistettiin toimivia ja paranneltavia asioita sekä lasten esittämiä toiveita. Näihin pohjautuen voidaan jatkoanalyysin avulla koostaa kuvaus asioista, joita erikoissairaanhoidon piirissä olevat lapset ja nuoret pitävät tärkeinä ja arvokkaina. Havainnot voidaan luokitella kolmeen teemaryhmään (suluissa merkitty kuinka moni osallistujista mainitsi nämä tutkimuksessa):

1. Fyysiset puitteet

- Toimivat ja viihtyisät tilat lapselle, nuorelle ja tämän perheelle $(\mathrm{N}=14 / 14)$ ja hyvä ilmapiiri, yksityisyys ( $N=12 / 14)$

2. Lapsen ja perheen kohtaaminen

- Käynnin helppous, selkeys ja nopeus ( $\mathrm{N}=13 / 14$, liittyy myös teemaan 1)

- Hoidon jatkuvuus ( $\mathrm{N}=9 / 14)$

- Yksilöllistä, lämmintä kohtaamista lapsen ikä ja tilanne huomioiden (ns. pehmeät arvot, $\mathrm{N}=14 / 14$ )

- Vanhempien mukanaolo tärkeää $(\mathrm{N}=12 / 14)$

3. Hoidon helppous ja järkevyys

- Hoito on perusteltua ja sairaala seuraa kehitystä sekä informoi lasta/perhettä esimerkiksi uusista hoitomuodoista $(\mathrm{N}=6 / 14)$

- Sairauden hoito on helppoa, kätevää ja miellyttävää ja lapsi tai nuori voi sairaudesta huoli- 
matta elää hyvää elämää ja kokea vapauden tunnetta $(\mathrm{N}=12 / 14)$

Näihin tärkeiksi ja arvokkaiksi koettuihin asioihin voidaan vaikuttaa eri tavoilla. Joitakin näistä asioista voidaan parantaa fyysisillä asioilla, toisiin voidaan taas vaikuttaa vuorovaikutustilanteissa ja osaa voidaan parantaa digitaalisten palveluiden avulla. Alla käydään esimerkin omaisesti läpi, minkälaisilla asioilla kuhunkin kolmeen ryhmään voidaan vaikuttaa fyysisesti ja vuorovaikutustilanteissa. Digitaalisten palveluiden mahdollisuudet asioiden parantamiseksi on nostettu omaksi otsikokseen seuraavaan lukuun.

Osaa havainnoista voidaan parantaa tai tehostaa fyysisesti:

- Selkeät opasteet

- Kutsukirjeen mukana selkeät ohjeet, minne saavutaan, missä ilmoittaudutaan jne.

- Tilasuunnittelussa huomioidaan lasten toiveet: maalauksia, tauluja, kasveja, tekemistä eri ikäryhmille, myös teineille, uudet mukavammat penkit odotustiloihin

Toisiin asioihin voidaan vaikuttaa vuorovaikutustilanteissa:

- Lapsen ja perheen kohtaaminen lapsen ikä ja elämän tilanne paremmin huomioon ottaen eli yksilöllinen, arvokas kohtaaminen

\section{Tulosten merkitys digitaalisten palveluiden kehittämi- sessä Uudessa lastensairaalassa}

Suunnittelemalla ja kehittämällä digitaalisia palveluita, voidaan osaan edellä mainituista asioista myös vaikuttaa. Seuraavassa on nostettu esiin ideoita, jotka perustuvat lasten ja nuorten esittämiin tarpeisiin. Osa näistä digitaalisten palveluiden ideoista on työn alla tai niitä kokeillaan jo tällä hetkellä ja osa voidaan toteuttaa lähitulevaisuudessa tai myöhemmin:
- Fyysiset puitteet:

- Terveyskylä.fi -infosivut jo toiminnassa. Terveyskylään on kehitteillä Lastentalo.fi -sivut, joilla voisi olla lastensairaalan pohjapiirrokset, jolloin etukäteen voi tutustua tiloihin, 3D-näkymä

- Lapsen ja perheen kohtaaminen

- Peli, missä lapsi tai nuori voi etukäteen tutustua sairaalan eri osastoihin ja toimenpiteisiin, koska esivalmistelu on todettu tärkeäksi [33]. Vastaava Päiki-Pörriäinen löytyy nyt jo pienille lapsille tehtynä päiväkirurgisesta hoitopäivästä [34].

- Lapsille ystävät ovat tärkeitä ja yhteydenpito tulisi mahdollistaa ja tehdä helpoksi myös sairaalassa, ilmainen WiFi ja langaton verkko

- Lastensairaalan sisäinen sähköinen ympäristö, jonne voi kirjautua ja etsiä kavereita, jopa ennen kuin tulee sairaalaan ja voi jättää viestin tai ilmoituksen muille

- Chat hoitajan tai lääkärin kanssa tarjoaa helpon yhteyden ja reaaliaikaista tietoa

- "Kuumalinja" omalle hoitajalle tai lääkärille

- Digitaalinen tiedotuskanava lääkärin ja vanhempien välillä, mikäli vanhemmat eivät pääse kontrollikäynnille mukaan

- Etukäteen sähköisesti täytettävät lomakkeet tai kyselyt taudin oireista (esimerkiksi suolistosairaille) ja diabeetikoille mahdollisuus ladata insuliinipumpun/mittarin tiedot lääkärille ennen käyntiä, jolloin lääkäri voi tutustua näihin etukäteen ja käynnin kokonaiskesto voi lyhentyä

- Hoidon helppous ja rationaalisuus

- Sähköisten palveluiden kokonaisuus, joka tarjoaa tietoa eri sairauksista, hoidoista ja uusista hoitomuodoista, ja toimii kehitteillä olevan Lastentalo.fi-sivuston alaisuudessa. Tietoa voisi löytyä sekä kirjallisena että tietoiskuvideoilla ja tarjota linkkejä tieteellisiin julkaisuihin

- Uusien yhteistyökanavien käyttömahdollisuuksien kokeilu: whatsapp, eri sähköiset ympäristöt, chat 


\section{Vertailu aiempiin tutkimuksiin}

Tutkimuksen avulla selvitettiin lasten ja nuorten ajatuksia omasta potilaskokemuksestaan. He arvostivat hoitohenkilökunnan keskustelua heidän kanssaan sairauden lisäksi myös muista asioista, kuten kuulumisista ja vapaa-ajasta. MLL:n lasten ja nuorten puhelimen vuosiraportissa [20] näkyy sama lapsen ja nuoren tarve keskustella asioistaan kuuntelevan aikuisen kanssa, joka ei välttämättä kuulu omaan perheeseen tai lähipiiriin.

Lasten ja nuorten terveyspalvelujen käyttöä ja sairaalassaoloa on aiemmin tutkittu jonkin verran. Sairaalassa viihtymiseen liittyvät asiat on tunnistettu muuallakin $[21,22,23,24,25,27]$, ja monessa tutkimuksessa on mainittu muun muassa lelut, pelit, televisio ja videot. Hoitohenkilökunnan tapa kohdata lapsi ja nuori oli toinen yleinen tulos $[21,22,23,24,27]$. Vastaajat toivoivat muun muassa lämmintä, ystävällistä ja kunnioittavaa kohtaamista, jossa heitä kuunnellaan ja hoitohenkilökunnalla on herkkyyttä ja tilannetajua ymmärtää millaisista asioista voidaan keskustella vanhempien läsnä ollessa. Monissa tutkimuksissa osallistujat olivat ottaneet kantaa sairaalan tiloihin [21, 23, 24, 27] ja toivoneet muun muassa lapsiystävällisiä odotustiloja ja valaistuksen himmentämistä öisin.

Myös lasten ja nuorten kuolemanpelko tuli tutkimuksissa esille [21, 22]. Tässä tutkimuksessa ei tullut esiin kuolemanpelkoa, mutta sairauden lopullisuutta ja vaikutusta loppuelämään muutamat lapset ja nuoret kyllä pohtivat. Forsnerin tutkimusryhmä on esittänyt havaintoja, että lapset yrittivät erilaisin keinoin paeta epämukavaa oloa sairaalassa ja myös karkottaa sairauden pois [22]. Videopäiväkirjamenetelmällä saatiin selville, että muutamat osallistujat toivoivat inmelaitetta tai -hoitoa, joka parantaisi heidän sairautensa. Usean tutkimuksen osallistujan vastauksissa nousivat esille non-invasiiviset laitteet ja hoitotoimenpiteet [21, 22, 26, 27], vanhempien tai perheen läsnäolon tärkeys [21, 22, 23, 27], lasten ja nuorten tiedon tarve $[21,23,24,27]$, hoitohenkilökunnan jatkuvuus [23, 24, 27], diagnoosin pohtiminen $[22,27]$ ja yksityisyyden kaipuu $[24,27]$.

Aiemmissa tutkimuksissa ei juurikaan ole nostettu esille digitaalisia palveluja ja niiden mahdollisuuksia vaikuttaa potilaskokemuksiin lastensairaalaympäristössä. Ainoastaan Curtis ja muut tutkijat mainitsevat internetsivuilleen kehittämänsä kyselyn, jota he hyödynsivät tiedonkeruussa [24]. Tutkimuksen jälkeen internetsivu säilytettiin ja se toimi lapsille ja nuorille mahdollisena palautekanavana. Nuoria muun muassa rohkaistiin äänestämään sivuilla muutosten priorisoinnista. Tässä artikkelissa raportoidussa tutkimuksessa tunnistettiin digitaalisten palvelujen mahdollisuudet vastata lasten ja nuorten tiedon tarpeeseen sairaudestaan.

\section{Tutkimuksen arviointi}

Tässä artikkelissa kuvatun tutkimuksen uutuusarvo kumpuaa tavoitteesta ymmärtää lasten ja nuorten kokemuksia, sekä näihin liittyen heijastella digitaalisten palveluiden mahdollisuuksia tukea parempaa potilaskokemusta. Artikkelissa esitettyjä ideoita digitaalisista palveluista voidaan hyödyntää paitsi Uudessa lastensairaalassa, jossa tällä hetkellä integroidaan digitaalisia palveluita perinteisiin palveluihin, myös muissa vastaavissa lastensairaaloissa. Hypoteesina on, että uusien digitaalisten palveluiden avulla nuoret saadaan aktivoitua itsehoitoon, ja ne voivat parantaa merkittävästi lasten ja nuorten kokonaiskokemusta lastensairaalassa.

Eettiset näkökulmat on tärkeä huomioida aineiston keruussa, analysoinnissa ja tulosten esittämisessä kun tutkimus toteutetaan lastensairaalakontekstissa. Tässä työssä kerätty tutkimusaineisto säilytetään luottamuksellisesti ja se on ainoastaan tutkijoiden käytössä. Kuvia ja suoria lainauksia käytetään vain kirjoittajan (NK) diplomityössä ja mahdollisissa julkaisuissa. Tulokset esitetään siten, että ketään osallistujaa ei voida tunnistaa tai yksilöidä, vain osallistujan sukupuoli, ikä ja diagnoosi kerrotaan kuvien ja lainauksien yhteydessä. Osa kuvista on myös jälkikäteen lavastettu vastaamaan alkuperäistä tilannetta.

Tutkimuksen yhtenä keskeisimpänä haasteena oli aiheen sensitiivisyys - lapset ja sairastaminen - mikä saattoi näkyä myös tutkimuksen osallistumishalukkuudessa. Kaikilla lapsilla ja nuorilla ei ollut halua tai voimia pohtia omaa sairastamistaan. Tutkimuksessa olikin varsin korkea kieltäytymisprosentti, 59 \%. On epäselvää, onko 
tämä vaikuttanut kerättyyn aineistoon lasten potilaskokemuksesta [27]. Jatkossa olisi hyvä ymmärtää myös näiden tutkimuksesta pois jääneiden nuorten ajatuksia potilaskokemuksestaan ja selvittää voidaanko heidän kauttaan saada esille uutta tietoa. Tässä tutkimuksessa suurin osa osallistujista oli osallistumaan motivoituneita tyttöjä. On mahdollista, että tutkimukseen osallistujat kokevat sairastamisensa eri tavalla ja antavat erilaista palautetta kuin teini-ikäiset pojat, joita ei kiinnosta osallistua. Lisäksi on huomioitava, että vaikka tähän tutkimukseen osallistuneilla on pitkäaikainen sairaus heidän loppuelämänsä ajan, on heillä kuitenkin toiveikkaammat ennusteet kuin esimerkiksi syöpäsairailla. Näin ollen lapset ja nuoret, joilla on syöpä, elinsiirto tai vakava tapaturma, voivat antaa erilaisia vastauksia tai painottaa eri asioita omassa potilaskokemuksessaan. Otos ei siis ole kattava tai kaikkia potilasryhmiä kuvaava. Otos on myös suhteellisen pieni, joten mitään suuria yleistyksiä ei voida tehdä vaan pikemmin osoittaa esille nousseita asioita ja tehdä arvioita ilmiöistä. Huolimatta pienestä aineistosta esiin nousseet teemat ovat yhteneviä aiempien tutkimusten löydösten kanssa.

Erityisesti lasten ja nuorten potilaskokemuksen mittaamisen mahdollisuuksia ei vielä kunnolla tunneta. Kirjoittajien tiedon mukaan tässä artikkelissa esitellyllä videopäiväkirjamenetelmällä toteutetulla tutkimuksella on uutuusarvoa, sillä kirjallisuudesta ei löydy tietoa muista vastaavista Suomessa toteutetuista potilaskokemustutkimuksista (samasta tutkimuksesta on aiemmin kirjoitettu kaksi menetelmäpainotteista julkaisua: [27, 35]). Tästä tutkimuksesta saadut kokemukset auttavat ymmärtämään, miten lapsilta ja nuorilta voidaan kerätä tietoa heidän potilaskokemuksestaan (menetelmän soveltuvuus tarkemmin kuvattu [27]) ja toisaalta minkälaisia asioita he nostavat tärkeiksi ja arvokkaiksi. Digitaaliset palvelut voivat kehittyessään ja yleistyessään vaikuttaa myönteisesti myös lasten potilaskokemukseen. Toiveena onkin saada ne tulevaisuudessa nivottua luontevasti osaksi lapsen muuta potilaspolkua.

\section{Kiitokset}

Tässä artikkelissa käsitelty aineisto on kerätty keväällä 2016 HYKS:n Lastensairaalan reuma-, diabetes- ja suo- listopoliklinikoiden potilailta. Kirjoittajat haluavat kiittää tutkimukseen osallistuneita lapsia ja nuoria sekä heidän perheitään, kyseisten poliklinikoiden hoitajia sekä Uusi lastensairaala-hanketta. Lisäksi kiitämme Mika P. Niemistä tutkimuksen aikaisesta ohjauksesta ja Lapsustutkimushankkeen rahoittajatahoa Tekesiä.

\section{Lähteet}

[1] Kaipio J, Tyllinen M, Nieminen M, Kushniruk A, Borycki E. Exploring Patient Experience PX. A workshop paper at $\mathrm{CHI} 2014$ workshop $\mathrm{HCl}$ Research in Healthcare: Evidence to Practice. The ACM CHI Conference on Human Factors in Computing Systems; 2014.

[2] Robison J. What is the "patient experience". Hospitals are becoming increasingly frustrated-and wasting money-trying to hit the wrong target. Gallup Management Journal Online 2010 S. 1-3.

[3] de Boer D, Delnoij D, Rademakers J. The discriminative power of patient experience surveys. BMC Health Serv Res. 2011 Dec 6;11:332. https://doi.org/10.1186/1472-6963-11-332

[4] Browne K, Roseman D, Shaller D, Edgman-Levitan S. Analysis \& commentary measuring patient experience as a strategy for improving primary care. Health Aff (Millwood). $2010 \quad$ May;29(5):921-5. https://doi.org/10.1377/hlthaff.2010.0238

[5] White K. Engaging patients to improve the healthcare experience. Healthcare Financial Management. Healthc Financ Manage. 2012 Jul;66(7):84-8.

[6] Beryl Instituutti. Beryl Instituutti luo määritelmän potilaskokemuksesta. Health and Beauty Close up. Beryl Instituutti; 2010 [Viitattu 23.9.2016]. Saatavissa: http://search.proquest.com/docview/751476621

[7] Savage E, Callery P. Weight and energy: parents' and children's perspectives on managing cystic fibrosis diet. Arch Dis Child. 2005 Mar;90(3):249-52. https://doi.org/10.1136/adc.2004.056804

[8] Oxford Dictionaries. "Experience". Kokemuksen määritelmä. [Viitattu 23.9.2016]. Saatavissa: www.oxforddictionaries.com 
[9] Käyttäjäkokemuksen määritelmät, määritelmä nr. 6 . [Viitattu 27.9.2016].

Saatavissa:

http://www.allaboutux.org/ux-definitions

[10] Greenfield G, Ignatowicz AM, Belsi A, Pappas Y, Car J, Majeed A, Harris M. Wake up, wake up! It's me! It's my life! patient narratives on person-centeredness in the integrated care context: a qualitative study. BMC Health Serv Res. 2014 Nov 29;14:619. https://doi.org/10.1186/s12913-014-0619-9

[11] Bleich SN, Özaltin E, Murray CJ. How does satisfaction with the health-care system relate to patient experience? Bull World Health Organ. 2009 Apr;87(4):271-8. https://doi.org/10.2471/BLT.07.050401

[12] Wong EL, Coulter A, Hewitson P, Cheung AW, Yam $\mathrm{CH}$, fai Lui S, Tam WWS, Yeoh EK. Patient experience and satisfaction with inpatient service: development of short form survey instrument measuring the core aspect of inpatient experience. PLoS One. 2015 Apr 10;10(4):e0122299.

https://doi.org/10.1371/journal.pone.0122299

[13] Needham BR. The truth about patient experience: what We Can learn from other industries, and How three Ps Can improve health outcomes, strengthen brands, and delight customers. J Healthc Manag. 2012 Jul-Aug;57(4):255-263.

[14] Manary MP, Boulding W, Staelin R, Glickman SW. The patient experience and health outcomes. N Engl J Med. 2013 Jan 17;368(3):201-203. https://doi.org/10.1056/NEJMp1211775

[15] Foot C, Fitzsimons B. The policy and practice of measuring patient experience. Nurs Manag (Harrow). 2011 Jun;18(3):18-19. https://doi.org/10.7748/nm2011.06.18.3.18.c8535

[16] Schembri S. Experiencing health care service quality: through patient's eyes. Aust Health Rev. 2015 Feb;39(1):109-116. https://doi.org/10.1071/AH14079

[17] Greenhalgh T, Hurwitz B. Narrative based medicine: why study narrative? BMJ. 1999 Jan 2;318(7175):48-50.

https://doi.org/10.1136/bmj.318.7175.48
[18] Launer J. New stories for old: Narrative-based primary care in Great Britain. Families, Systems, \& Health. 2006;24(3)336-344. https://doi.org/10.1037/10917527.24.3.336

[19] Lees C. Measuring the patient experience. Nurse Res. 2011;19(1):25-28.

https://doi.org/10.7748/nr2011.10.19.1.25.c8768

[20] Mannerheimin Lastensuojeluliitto. Lasten ja nuorten puhelimen vuosiraportti 2015. Mannerheimin Lastensuojeluliitto; 2016 [Viitattu 7.1.2017]. Saatavissa: https://www.mll.fi/@Bin/28476101/MLLn+Lasten+ja+n uorten+puhelimen+vuosiraportti+2015.pdf

[21] Coyne I. Children's experiences of hospitalization. J Child Health Care. 2006 Dec;10(4):326-336. https://doi.org/10.1177/1367493506067884

[22] Forsner M, Jansson L, Sørlie V. The experience of being ill as narrated by hospitalized children aged 7-10 years with short-term illness. J Child Health Care. 2005 Jun;9(2):153-165.

https://doi.org/10.1177/1367493505051406

[23] Carney T, Murphy S, McClure J, Bishop E, Kerr C, Parker J, Scott F, Shields C, Wilson L. Children's views of hospitalization: an exploratory study of data collection. J Child Health Care. 2003 Mar;7(1):27-40. https://doi.org/10.1177/1367493503007001674

[24] Curtis K, Liabo K, Roberts H, Barker M. Consulted but not heard: a qualitative study of young people's views of their local health service. Health Expect. 2004 Jun;7(2):149-156. https://doi.org/10.1111/j.13697625.2004.00265.x

[25] Sartain SA, Maxwell MJ, Todd PJ, Haycox AR, Bundred PE. Users' views on hospital and home care for acute illness in childhood. Health Soc Care Community. 2001 Mar;9(2):108-117. https://doi.org/10.1046/j.1365-2524.2001.00287.x

[26] Kortesluoma RL, Nikkonen M. 'I had this horrible pain': the sources and causes of pain experiences in 4to 11-year-old hospitalized children. J Child Health Care 2004 Sep;8(3):210-231. https://doi.org/10.1177/1367493504045822 
[27] Karisalmi N. Potilaskokemus lapsipotilaiden omin sanoin kerrottuna - Videopäiväkirjan soveltuvuus aineiston keruutavaksi. Diplomityö, Aalto-yliopisto, Espoo; 2016. 104 s.

[28] Cashmore A, Green P, Scott J. An ethnographic approach to studying the student experience: The student perspective through free form video diaries. A Practice Report. The International Journal of the First Year in Higher Education 2010;1(1):106-111. https://doi.org/10.5204/intjfyhe.v1i1.22

[29] Noyes A. Video diary: a method for exploring learning dispositions. Cambridge journal of education 2004:34(22):193-209. https://doi.org/10.1080/03057640410001700561

[30] Buchwald, D, Schantz-Laursen B, Delmar C. Video diary data collection in research with children: An alternative method. International Journal of Qualitative Methods. 2009;8(1):12-20. https://doi.org/10.1177/160940690900800102

[31] Rich M, Patashnick J. Narrative research with audiovisual data: Video intervention/prevention assessment
(VIA) and NVivo. International Journal of Social Research Methodology. 2002;5(3):245-261. https://doi.org/10.1080/13645570210166373

[32] Hirsjärvi S, Remes P, Sajavaara P. (toim.). Tutki ja kirjoita. Helsinki: Kustannusosakeyhtiö Tammi; 2007.

[33] Ellerton ML, Merriam C. Preparing children and families psychologically for day surgery: an evaluation. J Adv Nurs. $1994 \quad$ Jun;19(6):1057-1062. https://doi.org/10.1111/j.1365-2648.1994.tb01188.x

[34] Päiki-Pörriäinen. Lapsipotilas päiväkirurgiassa. Päijät-Häme. [Viitattu 3.1.2017]. Saatavissa: http://www.hyvis.fi/paijathame/fi/Sivut/PaikiPorriainen.aspx

[35] Karisalmi N, Nieminen MP. Selfies of Sickness: The Use of Video Diaries with Chronically III Children. Hyväksytty julkaistavaksi ja esitettäväksi Victoriassa Kanadassa 16.-19.2.2017 järjestettävässä ITCH 2017 -konferenssissa. 